Available online at http://jurnal.goretanpena.com/index.php/JSSR

\title{
MODEL DAN SIMULASI RANGKAIAN RLC MENGGUNAKAN APLIKASI MATLAB METODE SIMULINK
}

\author{
Ikhsan Parinduri \\ Sistem Komputer, STMIK Royal, Kisaran \\ e-mail: Ikhsanparinduri9@gmail.com
}

\begin{abstract}
The simulation approach begins with the development of a real system model. The model should be able to show how the various components in the system interact so that it really describes the behavior of the system. The RLC circuit is either a circuit connected with parallel or in series, but the circuit must consist of a capacitor; inductor; and resistors. RLC naming itself also has its own reasons, namely due to the name of the electrical symbol is usually on the capacitance; inductance and resistance respectively. This circuit will resonate in the same way that is-as the LC circuit.
\end{abstract}

Keywords: model and simulation, RLC series

\begin{abstract}
Abstrak: Pendekatan simulasi diawali dengan pembangunan model sistem nyata. Model tersebut harus dapat menunjukkan bagaimana berbagai komponen dalam sistem saling berinteraksi sehingga benar-benar menggambarkan perilaku sistem. Rangkaian RLC merupakan rangkaian baik yang dihubungkan dengan paralel ataupun secara seri, namun rangkaian tersebut harus terdiri dari kapasitor; induktor; dan resistor. Penamaan RLC sendiri juga memiliki alasan tersendiri, yaitu disebabkan nama yang menjadi simbol listrik biasanya pada kapasitansi; induktansi dan ketahanannya masing-masing. Rangkaian ini akan beresonansi dengan suatu cara yang sama yaitu sebagai Rangkaian LC.
\end{abstract}

Kata kunci: model dan simulasi, rangkaian RLC

\section{PENDAHULUAN}

Matlab merupakan bahasa
pemprograman tingkat tinggi yang dikembangkan oleh MathWorks dan dikhususkan untuk komputasi numerik, visualisasi dan pemrograman. Dengan memanfaatkan Matlab, pengguna dapat melakukan analisis data, mengembangkan algoritma dan membuat model maupun aplikasi.

Simulink pada Matlab adalah salah satu fitur dari Matlab untuk mensimulasi suatu desain atau model yang bersifat dinamis ataupun tertanam, simulasi ditujukan untuk mengukur kinerja dari suatu desain atau model sistem yang telah dirancang yang sesuai hasil yang di inginkan.

Rangkaian RLC merupakan rangkaian baik yang dihubungkan dengan paralel ataupun secara seri, namun rangkaian tersebut harus terdiri dari kapasitor; induktor dan resistor. Penamaan RLC sendiri juga memiliki alasan tersendiri, yaitu disebabkan nama yang 
Available online at http://jurnal.goretanpena.com/index.php/JSSR

menjadi simbol listrik biasanya pada kapasitansi; induktansi dan ketahanannya masing-masing. Rangkaian ini akan beresonansi dengan suatu cara yang sama yaitu-sebagai Rangkaian LC, bersamaan dengan terbentuknya osilator harmonik.

Model adalah alat yang sangat berguna untuk menganalisis maupun merancang sistem. Sebagai alat komunikasi yang sangat efisien, model dapat menunjukkan bagaimana suatu operasi bekerja dan mampu merangsang untuk berpikir bagaimana meningkatkan atau memperbaikinya. Model didefinisikan sebagai suatu deskripsi logis tentang bagaimana sistem bekerja atau komponen-komponen berinteraksi. Dengan membuat model dari suatu sistem maka diharapkan dapat lebih mudah untuk melakukan analisis.

Simulasi merupakan alat yang tepat untuk digunakan terutama jika diharuskan untuk melakukan eksperimen dalam rangka mencari komentar terbaik dari komponen-komponen sistem. Hal ini dikarenakan sangat mahal dan memerlukan waktu yang lama jika eksperimen dicoba secara riil. Dengan melakukan studi simulasi maka dalam waktu singkat dapat ditentukan keputusan yang tepat serta dengan biaya yang tidak terlalu besar karena semuanya cukup dilakukan dengan komputer.

Rumusan masalah dalam penelitian ini adalah bagaimana penerapan model simulasi Rangkaian RLC dengan menggunakan software Matlab metode simulink dapat diaplikasikan di materi Perkuliahan Elektronika Dasar.

Ruang lingkup pembahasan yang ada dalam penelitian ini adalah penerapan dan perancangan model simulasi menggunakan Matlab metode simulink untuk Rangkaian RLC.

Dalam penelitian ini ada beberapa tujuan yang hendak dicapai antara lain adalah memberi pemahaman kepada Mahasiswa tentang rangkaian RLC menggunakan software Matlab metode simulink. Hasil penelitian ini akan bermanfaat bagi mahasiswa untuk memberi pemahaman dan mempelajari tentang rangkaian RLC menggunakan software Matlab metode simulink.

\section{METODE}

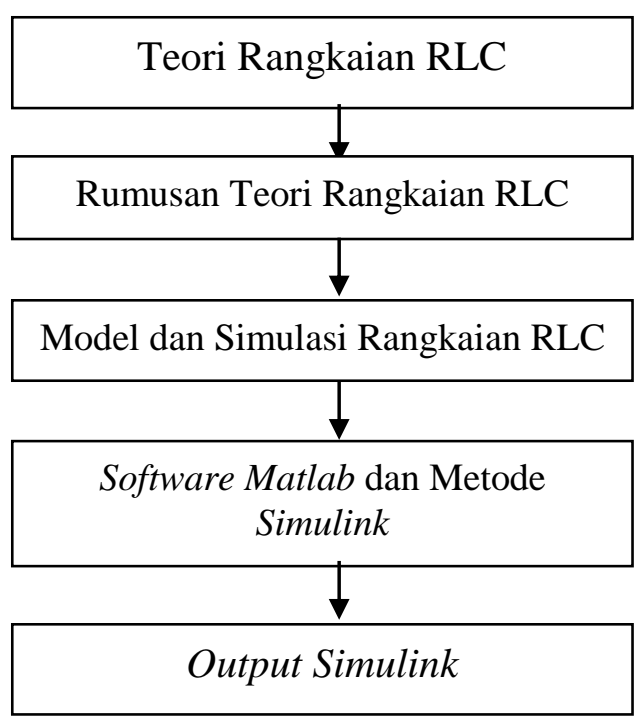

Gambar 1. Siklus Hidup Pengembangan Sistem

Pembelajaran Fisika dasar dan elektronika dalam penelitian ini adalah mensimulasikan rumusan listrik mengenai arus, tegangan dan daya listik dengan menggunakan software Matlab dengan metode simulink dapat dilakukan dengan beberapa tahap kerangka kerja.

Sebuah penelitian memerlukan metode pendekatan yang digunakan untuk memecahkan masalah yang akan diteliti demi mencapai tujuan penelitian. Metode yang digunakan pada penelitian ini adalah metode model dan simulasi dari teori yang ada.

Penelitian metode model dan simulasi dari teori yang ada. Dapat diartikan sebagai suatu penelitian yang berusaha untuk mengungkap hu-bungan antara dua variabel atau lebih. Penelitian eksperimen juga dapat difungsikan untuk mencari pengaruh suatu variabel terhadap variabel lainnya. Tujuan penelitian ini 
Available online at http://jurnal.goretanpena.com/index.php/JSSR

adalah untuk melihat sejauh mana penerapan metode simulink dalam pembelajaran fisika dasar dan elektronika dasar dalam rangkaian RLC.

Dalam Pengembangan suatu sistem pengajaran Fisika Dasar dan Elektronika Dasar dapat dirumuskan teori pemahaman tentang Rangkaian RLC dan pengembangan sistem model dan simulasi menggunakan simulink dari program Matlab.

Output metode Simulasi menggunakan software Matlab berupa blok diagam tentang media pembelajaran Fisika dasar dan elektronika Dasar berupa perhitungan dari rumusan tentang tentang listrik, arus, tegangan dan daya listrik dan pengembangan sistem model dan simulasi menggunakan simulink dari program Matlab.

Simulink adalah graphical Extension Matlab untuk memodelkan dan mensimulasikan sebuah sistem. Dalam simulink, sistem digambarkan sebagai sebuah block diagram, dian-taranya transfer function, summing junction, di dalamnya terdapat pula virtual input dan output device seperti function generator dan oscilloscope. Sedangkan pada simulink, data dari berbagai block dikirim ke block lainnya dihubungkan dengan garis.

Elemen dasar dari Simulink adalah block dan lines. Block digunakan untuk mengenerate, modify, combine, output dan display signals. Lines digunakan untuk mentransfer sinyal dari satu block ke block lainnya.

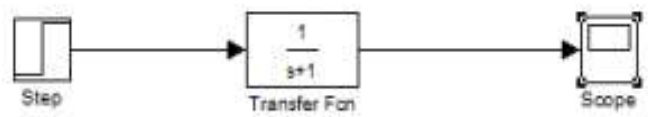

Gambar 2. Block diagram Simulink

Elektronika Dasar adalah suatu standar kompetensi yang ada ber-tujuan untuk memberikan pengetahuan maupun keterampilan terhadap maha-siswa mengenai pemahaman mengenai dasardasar elektronika dasar.

Dalam penelitian ini akan dibahas tentang model dan simulasi pembelajaran Fisika dasar dan Elektronika mengenai Listrik, Daya, Arus dan Tegangan Listrik dan Rangkaian RLC.

Jika sebuah resistor dilewati arus AC sebesar I maka pada resistor akan terdapat tegangan sebesar $\mathrm{Vr}=\mathrm{R}$ I. Sehingga jika arus membesar maka tegangan pada resistor juga akan membesar. Demikian sebaliknya jika I mengecil, Vr juga mengecil.

$$
\mathrm{V}_{\mathrm{R}}=\mathrm{R} \times \mathrm{I}
$$

Pada rangkaian $\mathrm{RL}$ seri, kedua komponen $\mathrm{R}$ dan $\mathrm{L}$ akan dilewati arus yang sama, misalnya I. Sehingga pada $R$ akan muncul tegangan VR dan pada $\mathrm{L}$ akan muncul tegangan VL, dimana:

$$
\mathrm{VL}=\mathrm{X}_{\mathrm{L}} \mathrm{x} \mathrm{I}
$$

Pada rangkaian LC seri, kedua komponen $\mathrm{L}$ dan $\mathrm{C}$ akan dilewati arus yang sama, misalnya I. Sehingga pada L akan muncul tegangan VLdan pada $\mathrm{C}$ akan muncul tegangan $\mathrm{VC}$, dimana:

$$
\mathrm{VC}=\mathrm{X}_{\mathrm{C}} \mathrm{x} \mathrm{I}
$$

\section{HASIL DAN PEMBAHASAN}

Penerapan model simulasi rangkaian RLC dengan menggunakan software Matlab metode simulink dapat diaplikasikan di materi Perku-liahan fisika dasar dan Elektronika Dasar. Dalam hal ini penggunaan program matlab dengan 
Available online at http://jurnal.goretanpena.com/index.php/JSSR

metode simulink yang mana teori dasar dapat di simulasikan kedalam bentuk tampilan dalam pemahaman mengenai rangkain RLC.

Menentukan kompoen-komponen inputan melalui tampilan dari
Simulink Library Brower terdiri dari: (1) Electrical Sources: Komponen DC Voltage Source, (2) Element: Kompo-nen Series RLC Branch, (3) Measurement: Kompoen Voltage Measurement

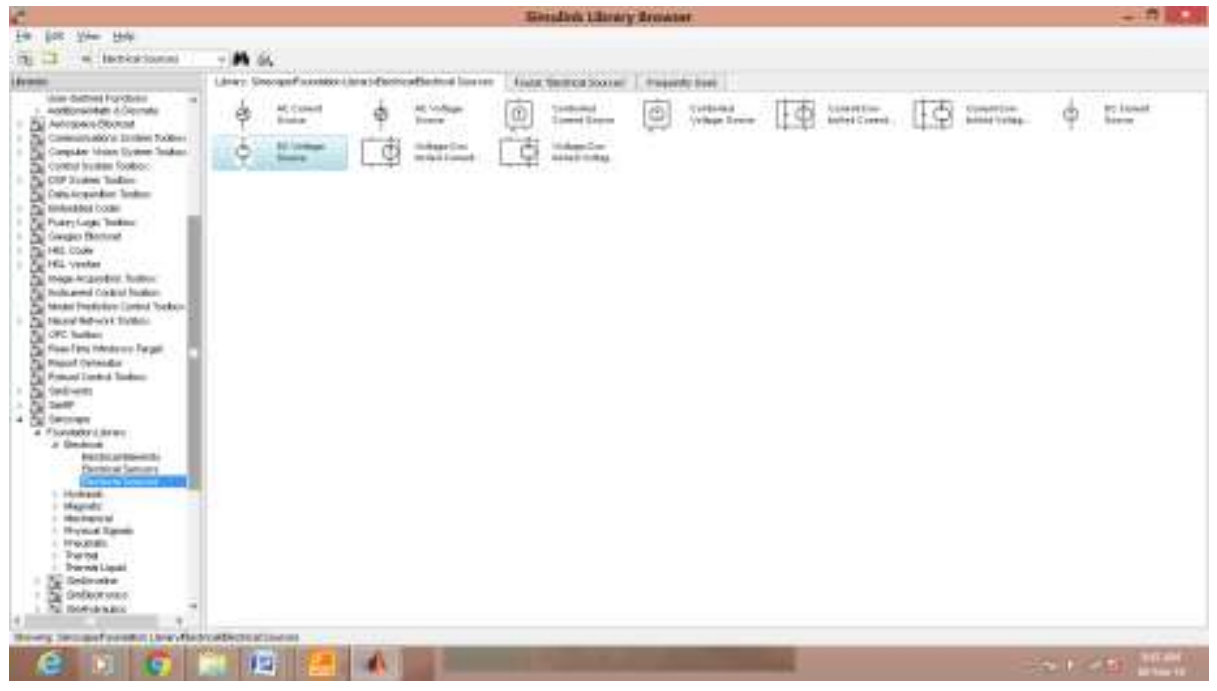

Gambar 3. Electrical Sources - Komponen DC Voltage Source

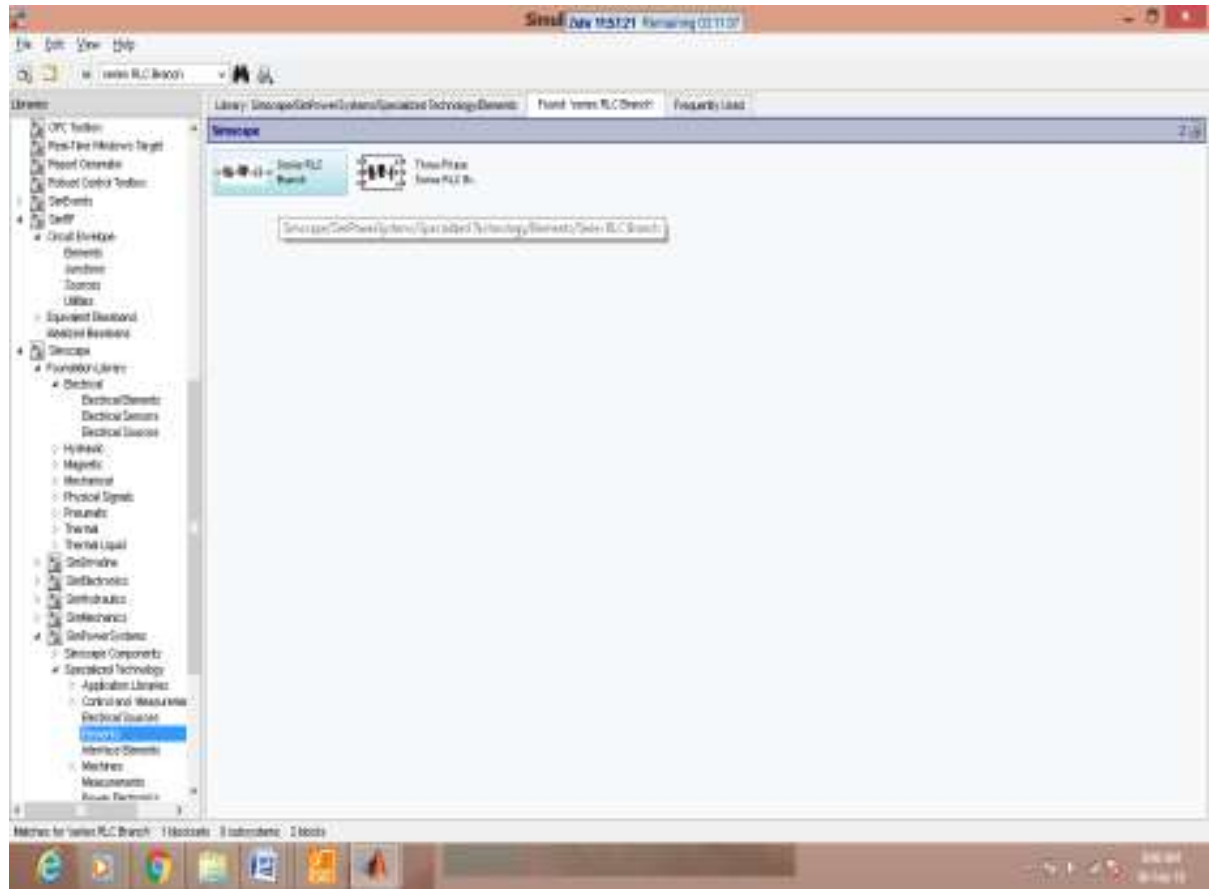

Gambar 4. Electrical Sources - Komponen DC Voltage Source 
Available online at http://jurnal.goretanpena.com/index.php/JSSR

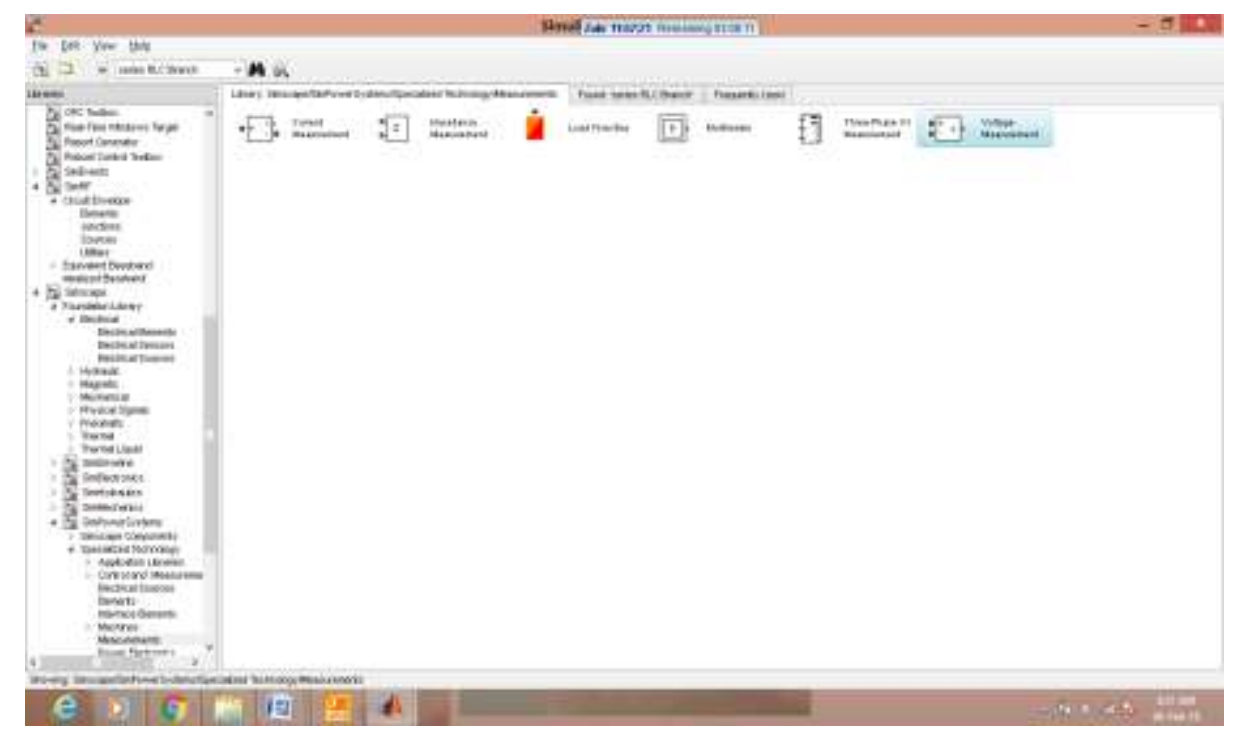

Gambar 5. Measurement-Komponen Voltage Measurement

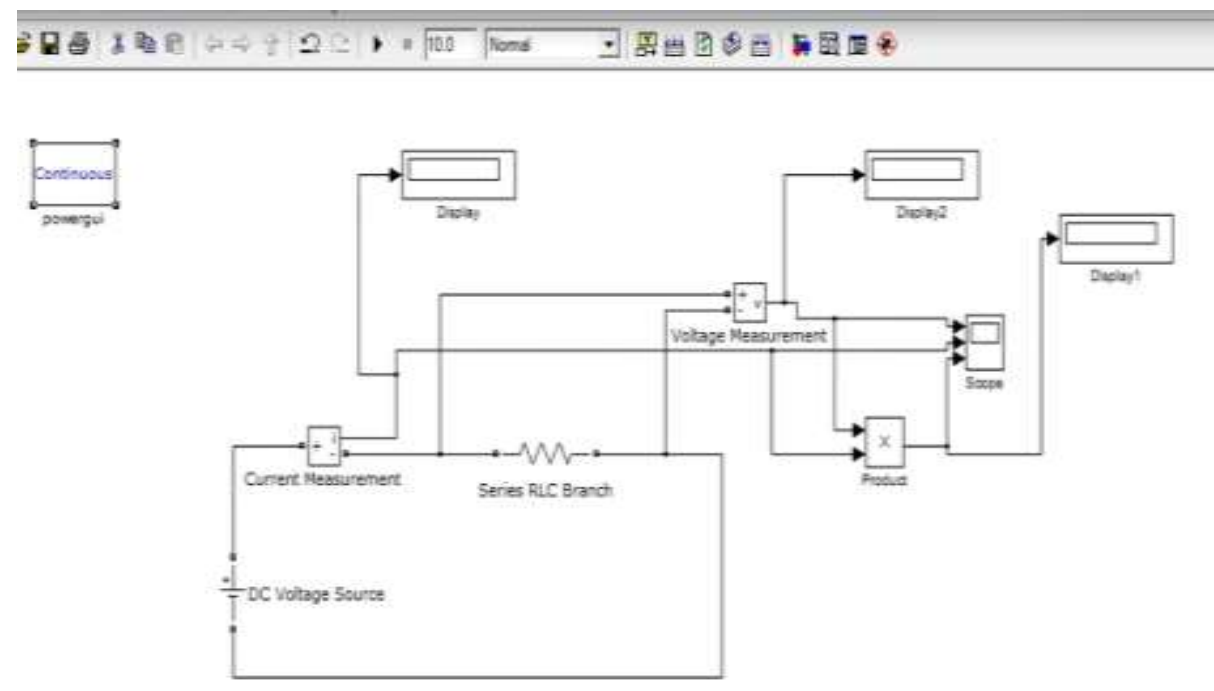

Gambar 6. Output Rangkaian RLC dengan metode Simulink

\section{SIMPULAN}

Berdasarkan hasil pengujian yang dilakukan terhadap aplikasi dapat disimpulkan beberapa hal diantranya adalah dengan aplikasi ini dapat terbantu untuk membuat model dan simulasi rangkaian RLC dalam pembelajaran fisika dasar dan elektronika dasar, tampilan program matlab dengan metode simulink membuat persamaan antara teori yang ada dengan bentuk model dan simulasi. 
Available online at http://jurnal.goretanpena.com/index.php/JSSR

\section{DAFTAR PUSTAKA}

E. Johnson. D, R. Johnson. J, L. John. H. 1989. Electric Circuit Analysis. New Jersey: Prentice Hall,

H. Rashid, M. 1993. Power Electronics: Circuits, Devices, and Applications (2nd Edition). New York: Prentice Hall

Kocalmis Bilham. A, Akbal. E. 2015. Modeling and Simulation of Two-Level Space Vector PWM Inverter Using Photovoltaic Cells As DC Source. International Journal Of Electronic. 2(4): 311 - 317.
O. Lopez, R. Teodorescu, F. Freijedo and J. DovalGandoy, 2007. Leakage current evaluation of a singlephase transformerless PV inverter connectedto the grid. APEC 07 - Twenty-Second Annual IEEE Applied Power Electronics Conference and Exposition, Anaheim. Pp 907 $-912$

W. Hart, D. 2011 Power Electronic. New York: Mc Graw-Hill Companies 